\title{
Early Frasnian ostracods from the Arche quarry (Dinant Synclinorium, Belgium) and the Palmatolepis punctata Isotopic Event
}

Jean-Georges Casier and Ewa Olempska

Acta Palaeontologica Polonica 53 (4), 2008: 635-646 doi:http://dx.doi.org/10.4202/app.2008.0408

Ostracods from the Arche quarry at Frasnes are analysed. Twenty-seven species are recognised in the Chalon Member and in the very base of the Arche Member of the Moulin Liénaux Formation. Three new species: Scrobicula gracilis, Microcheilinella archensis, and Bairdia (Rectobairdia) chalonensis, and one subspecies Plagionephrodes laqueus praelaqueus, are proposed. The fauna is in the Favulella lecomptei Zone based on metacopid ostracods and belongs to the Eifelian Mega-Assemblage. Ostracods are indicative of a regressive trend from a moderately deep poorly oxygenated marine environment below fair weather wave base to very shallow well oxygenated and agitated environments. Comparison of the ostracod fauna present in the Arche quarry with faunas described from the Frasnes railway section and from the Lion quarry shows that ostracods did not suffer a crisis during the Palmatolepis punctata Conodont Zone and close to the Early-Middle Frasnian boundary.

Key words: Ostracoda, Palmatolepis punctata Event, systematic, palaeoecology, Dinant Synclinorium, Frasnian, Belgium.

Jean-Georges Casier [casier@ naturalsciences.be], Département de Paléontologie, Institut royal des Sciences naturelles de Belgique, Rue Vautier 29, B-1000 Bruxelles, Belgium; Ewa Olempska [olempska@twarda.pan.pl], Instytut Paleobiologii PAN, ul. Twarda 51/55, PL-00-818 Warszawa, Poland.

This is an open-access article distributed under the terms of the Creative Commons Attribution License (for details please see creativecommons.org), which permits unrestricted use, distribution, and reproduction in any medium, provided the original author and source are credited. 
Fof Full text $(782.7 \mathrm{kB})$ 